\title{
Antiprotozoal Germacranolide Sesquiterpene Lactones from Tanacetum sonbolii
}

Authors

Sahar Mofidi Tabatabaei ${ }^{1}$, Samad Nejad Ebrahimi ${ }^{1}$, Peyman Salehi ${ }^{1}$, Ali Sonboli ${ }^{2}$, Marzieh Tabefam ${ }^{1}$, Marcel Kaiser ${ }^{3,4}$, Matthias Hamburger ${ }^{5}$, Mahdi Moridi Farimani ${ }^{1}$

Affiliations

1 Department of Phytochemistry, Medicinal Plants and Drugs Research Institute, Shahid Beheshti University, G.C., Evin, Tehran, Iran

2 Department of Biology, Medicinal Plants and Drugs Research Institute, Shahid Beheshti University, G.C., Evin, Tehran, Iran

3 Swiss Tropical and Public Health Institute, Basel, Switzerland

4 University of Basel, Basel, Switzerland

5 Pharmaceutical Biology, Pharmacenter, University of Basel, Basel, Switzerland

Key words

Tanacetum sonbolii, Asteraceae, sesquiterpene lactone, electronic circular dichroism, antiprotozoal activity, Trypanosoma brucei rhodesiense

received June 28,2018

revised December 9,2018

accepted December 16, 2018

Bibliography

DOI https://doi.org/10.1055/a-0824-1294

Published online January 8, 2019 | Planta Med 2019; 85: 424430 @ Georg Thieme Verlag KG Stuttgart · New York I ISSN 0032-0943
Correspondence

Dr. Samad Nejad Ebrahimi

Department of Phytochemistry, Medicinal Plants and Drugs Research Institute, Shahid Beheshti University, G.C. Daneshjou Boulevard, Evin, Tehran 1983969411, Iran Phone: + 982122431783 , Fax: + 982122431783

s_ebrahimi@sbu.ac.ir

Correspondence

Dr. Mahdi Moridi Farimani

Department of Phytochemistry, Medicinal Plants and Drugs Research Institute, Shahid Beheshti University, G.C. Daneshjou Boulevard, Evin, Tehran 1983969411, Iran Phone: + 982122431783 , Fax: + 982122431783 m_moridi@sbu.ac.ir Supporting information available online at http://www.thieme-connect.de/products

\section{ABSTRACT}

A phytochemical investigation of extracts from flowers and aerial parts of Tanacetum sonbolii afforded 7 new germacranolide sesquiterpene lactones. The structures were established by a combination of 1- and 2-dimensional nuclear magnetic resonance spectroscopy, high-resolution mass spectrometry, and electronic circular dichroism. The in vitro antiprotozoal activity of the compounds against Trypanosoma brucei rhodesiense and cytotoxicity against rat myoblast (L6) cells were determined. Compounds 4 and 5 showed $\mathrm{IC}_{50}$ values of 5.1 and $10.2 \mu \mathrm{M}$ and selectivity indices of 3.9 and 4.0 , respectively.

\section{Introduction}

Protozoan parasites cause serious public health problems in many parts of the world, particularly in Sub-Saharan Africa [1]. No vaccines are currently available for protozoan diseases, and antiprotozoal strategies rely on vector control and pharmacotherapy for infected patients. The treatment options for sleeping sickness (human African trypanosomiasis) remain insufficient, in particular for the late stage of the disease [2,3]. Given the successful track record of natural product leads such as quinine and artemisinin [4], a continued search for new antiprotozoal compounds from higher plants is warranted.

The genus Tanacetum (Asteraceae) comprises approximately 200 species that occur in many regions of the northern hemisphere [5]. Of the 36 Tanacetum species growing in Iran, a total of 16 are endemic [6]. Tanacetum sonbolii Mozaff. grows in Takab, West Azerbaijan Province of Iran, and has been recently identified as an endemic species [7-9]. $\alpha$-Cadinol, globulol, and 1,8-cineole were identified as major compounds in the essential oil [10], which was shown to possess antioxidant, anti-seizure, and pain re- 

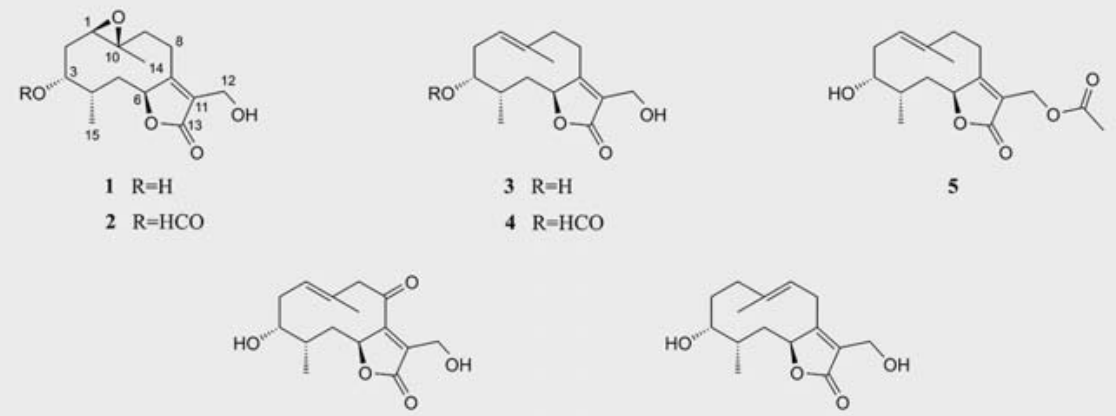

6

Fig. 1 Structures of compounds 1-7.

- Table $1{ }^{13} \mathrm{C}$ NMR (125 MHz) spectroscopic data of $1-7$ in $\mathrm{CDCl}_{3}$ ( $\delta$ in ppm).

\begin{tabular}{|c|c|c|c|c|c|c|c|}
\hline Position & 1 & 2 & 3 & 4 & 5 & $6^{a}$ & 7 \\
\hline 1 & 61.7 & 61.2 & 126.1 & 124.7 & 126.2 & 125.9 & 29.7 \\
\hline 2 & 27.4 & 25.6 & 37.2 & 37.2 & 27.4 & 36.8 & 35.5 \\
\hline 3 & 74.1 & 75.0 & 73.8 & 75.0 & 74.0 & 75.4 & 73.9 \\
\hline 4 & 37.1 & 34.4 & 41.1 & 34.5 & 37.1 & 38.7 & 36.8 \\
\hline 5 & 37.2 & 36.8 & 38.4 & 36.8 & 35.5 & 23.1 & 37.2 \\
\hline 6 & 82.0 & 81.0 & 82.1 & 81.4 & 81.7 & 81.8 & 82.1 \\
\hline 7 & 166.0 & 166.0 & 168.6 & 168.0 & 168.6 & 168.6 & 166.9 \\
\hline 8 & 23.0 & 22.8 & 23.0 & 25.6 & 23.8 & 210.0 & 23.0 \\
\hline 9 & 35.6 & 35.4 & 35.5 & 35.4 & 37.2 & 37.3 & 125.7 \\
\hline 10 & 60.7 & 60.7 & 134.3 & 136.0 & 132.4 & 133.9 & 134.3 \\
\hline 11 & 126.3 & 126.0 & 125.7 & 126.2 & 122.7 & 125.5 & 126.3 \\
\hline 12 & 54.6 & 53.7 & 54.2 & 54.3 & 54.9 & 53.5 & 54.1 \\
\hline 13 & 173.8 & 171.0 & 174.2 & 173.9 & 170.8 & 173.9 & 174.1 \\
\hline 14 & 17.0 & 16.9 & 17.0 & 17.0 & 17.0 & 17.9 & 17.0 \\
\hline 15 & 19.9 & 19.6 & 20.1 & 19.9 & 19.8 & 19.7 & 19.9 \\
\hline $\mathrm{HCO}$ & - & 161.0 & & 160.1 & & & \\
\hline $\mathrm{CH}_{3} \mathrm{CO}$ & & & & & 20.8 & & \\
\hline $\mathrm{CH}_{3} \mathrm{CO}$ & & & & & 169.7 & & \\
\hline
\end{tabular}

lieving properties [10-13]. In contrast, nonvolatile constituents of the species have not been studied so far. In a continued effort to discover new bioactive secondary metabolites from endemic Iranian plants [14-16], we here report on the isolation, structure elucidation, and in vitro antitrypanosomal activity of 7 new germacranolide sesquiterpene lactones from the aerial parts and flowers of $T$. sonbolii.

\section{Results and Discussion}

Sesquiterpene lactones 1,3 , and 5 were isolated from the flowers and $2,4,6$, and 7 from the aerial parts of $T$. sonbolii ( $\bullet$ Fig. 1 ). The structure elucidation was achieved using extensive NMR spectroscopy and HRESI-TOFMS, and the absolute configuration was es- tablished by a comparison of experimental and calculated electronic circular dichroism (ECD) spectra.

Compound 1 was obtained as a white amorphous powder. The HRESIMS of 1 showed a molecular ion at $m / z 283.1543[\mathrm{M}+\mathrm{H}]^{+}$ (calcd. 283.1540), indicating a molecular formula of $\mathrm{C}_{15} \mathrm{H}_{22} \mathrm{O}_{5}$ and 5 indices of hydrogen deficiency. The ${ }^{13} \mathrm{C}$ NMR spectrum ( $\vee$ Table 1) showed 15 carbon resonances, which were assigned with the aid of HSQC and DEPTQ spectra as 1 methyls, 5 methylenes, 4 methines, and 4 quaternary carbons. The ${ }^{1} \mathrm{H}$ NMR spectrum ( $\triangleright$ Table 2) displayed the characteristic signals of 2 aliphatic methyl groups at $\delta_{H} 0.94$ and $1.43,3$ oxygenated methine protons at $\delta_{H} 3.48,4.11$, and 5.78 , and 1 oxygenated methylene proton at $\delta_{H}$ 4.33. The NMR data of 1 were similar to those of germacranolide sesquiterpene lactones that had been reported previously 
- Table $2{ }^{1} \mathrm{H}$ NMR $\left(500 \mathrm{MHz}\right.$ ) data spectroscopic of $1-7$ in $\mathrm{CDCl}_{3}$ ( $\delta$ in ppm, $J$ in $\mathrm{Hz}$ ).

\begin{tabular}{|c|c|c|c|c|c|c|c|}
\hline Position & 1 & 2 & 3 & 4 & 5 & 6 & 7 \\
\hline 1 & $3.48 \mathrm{~d}(10.5)$ & $3.26 \mathrm{~d}(11.5)$ & $5.73 \mathrm{brs}$ & $5.60 \mathrm{brs}$ & $5.86 \mathrm{brs}$ & 5.75 br s & $1.22 \mathrm{~m}$ \\
\hline $2 \beta$ & $1.60 \mathrm{ddd}(15.0,10.5,1.0)$ & $1.74 \mathrm{dd}(16.0,11.5)$ & $2.24 \mathrm{~m}$ & $2.55 \mathrm{~m}$ & $2.46 \mathrm{~m}$ & $2.27 \mathrm{~m}$ & $2.25 \mathrm{~m}$ \\
\hline $2 \alpha$ & $2.29 \mathrm{~m}$ & $2.19 \mathrm{dd}(16.0,5.5)$ & $2.42 \mathrm{~m}$ & & & $2.44 \mathrm{~m}$ & $2.45 \mathrm{~m}$ \\
\hline 3 & $4.11 \mathrm{brd}(5.5)$ & 5.06 br s & 3.77 br s & $4.94 \mathrm{brs}$ & $3.82 \mathrm{brs}$ & $3.77 \mathrm{~m}$ & $3.77 \mathrm{~m}$ \\
\hline 4 & $2.37 \mathrm{~m}$ & $\begin{array}{l}1.25 \mathrm{~m} \\
2.25 \mathrm{~m}\end{array}$ & $2.12 \mathrm{~m}$ & $2.24 \mathrm{~m}$ & $2.18 \mathrm{~m}$ & $2.12 \mathrm{~m}$ & $2.12 \mathrm{~m}$ \\
\hline $5 \beta$ & $1.38 \mathrm{~m}$ & $1.25 \mathrm{~m}$ & $1.07 \mathrm{~m}$ & $1.17 \mathrm{~m}$ & $1.33 \mathrm{~m}$ & $2.38 \mathrm{~m}$ & $1.10 \mathrm{~m}$ \\
\hline $5 \alpha$ & $1.90 \mathrm{dd}(15.0,12.0$ & $1.86 \mathrm{~m}$ & $1.85 \mathrm{~m}$ & $1.90 \mathrm{~m}$ & & $3.10 \mathrm{~m}$ & $1.83 \mathrm{~m}$ \\
\hline 6 & $5.78 \mathrm{~d}(12.0)$ & $5.36 \mathrm{~d}(9.0)$ & $5.6 \mathrm{brs}$ & 5.10 brs & $5.70 \mathrm{~m}$ & 5.70 brs & $5.24 \mathrm{~s}$ \\
\hline $8 \alpha$ & $2.44 \mathrm{dd}(16.5,13.0)$ & $2.51 \mathrm{~m}$ & $2.42 \mathrm{~m}$ & $2.45 \mathrm{~m}$ & $2.40 \mathrm{~m}$ & - & $2.40 \mathrm{~m}$ \\
\hline $8 \beta$ & 3.14 ddd $(16.5,7.0,1.5)$ & $3.14 \mathrm{ddd}(16.5,7.5,1.0)$ & $2.92 \mathrm{dd}(11.5,3.5)$ & $2.99 \mathrm{~m}$ & $2.97 \mathrm{~m}$ & & $2.92 \mathrm{~m}$ \\
\hline $9 \alpha$ & $1.31 \mathrm{~m}$ & $1.27 \mathrm{~m}$ & $2.31 \mathrm{~m}$ & $2.13 \mathrm{~m}$ & $1.19 \mathrm{~m}$ & $1.12 \mathrm{~m}$ & $5.75 \mathrm{brs}$ \\
\hline $9 \beta$ & $2.35 \mathrm{~m}$ & $2.27 \mathrm{~m}$ & $2.40 \mathrm{~m}$ & $2.38 \mathrm{~m}$ & $1.87 \mathrm{~m}$ & $1.85 \mathrm{~m}$ & \\
\hline 12 & $4.33 \mathrm{~d}(4.0)$ & $4.10 \mathrm{br} \mathrm{s}$ & 4.22 br s & $4.14 \mathrm{brs}$ & $4.70 \mathrm{brs}$ & $4.20 \mathrm{br} \mathrm{s}$ & $4.2 \mathrm{brs}$ \\
\hline 14 & $1.43 \mathrm{~s}$ & $1.38 \mathrm{~s}$ & $1.64 \mathrm{~s}$ & $1.69 \mathrm{~s}$ & $1.70 \mathrm{~s}$ & $1.68 \mathrm{~s}$ & $1.66 \mathrm{~s}$ \\
\hline 15 & $0.94 \mathrm{~d}(7.0)$ & $0.99 \mathrm{~d}(7.0)$ & $0.89 \mathrm{~d}(6.5)$ & $0.95 \mathrm{~d}(7.5)$ & $0.93 \mathrm{~d}(6.5)$ & $0.91 \mathrm{~d}(6.5)$ & $0.88 \mathrm{~d}(6.5)$ \\
\hline $\mathrm{HCO}$ & & $8.00 \mathrm{~s}$ & & $8.04 \mathrm{~s}$ & & & \\
\hline $\mathrm{CH}_{3} \mathrm{CO}$ & & & & & $1.99 \mathrm{~s}$ & & \\
\hline
\end{tabular}
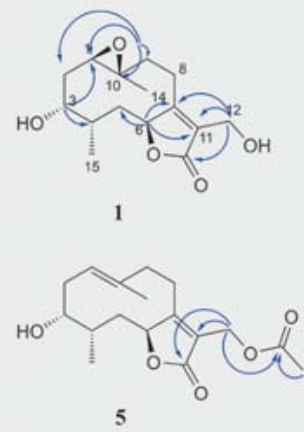
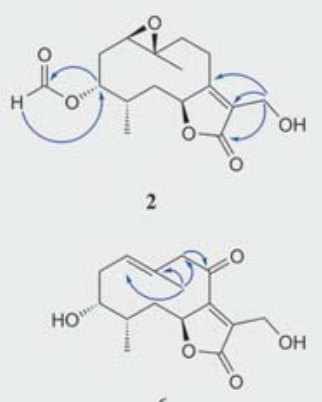
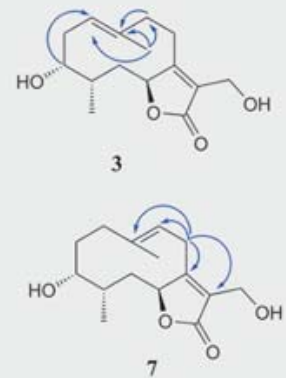

- Fig. 2 Selected HMBC correlations.

from Tanacetum species [17]. The ${ }^{1} \mathrm{H}-{ }^{1} \mathrm{H}$ COSY and $\mathrm{HSQC}$ spectra indicated the presence of 3 contiguous fragments: $-\mathrm{CH}(1)-\mathrm{CH}_{2}$ (2)- $\mathrm{CH}(3)-\mathrm{CH}(4)-\mathrm{CH}_{2}(5)-\mathrm{CH}(6)-,-\mathrm{CH}(4)-\mathrm{CH}_{3}(15)-$, and $-\mathrm{CH}_{2}(8)-$ $\mathrm{CH}_{2}(9)$-. $\mathrm{HMBC}$ correlations from $\mathrm{H}_{2}-12\left(\delta_{H} 4.33\right)$ to the carbonyl carbon $\left(\mathrm{C}-13, \delta_{C} 173.8\right)$ and to olefinic carbons $\mathrm{C}-11\left(\delta_{C} 126.3\right)$ and $\mathrm{C}-7\left(\delta_{C} 166.0\right)$, from $\mathrm{H}_{2}-8\left(\delta_{H} 3.14\right)$ to $\mathrm{C}-7, \mathrm{C}-11, \mathrm{C}-6\left(\delta_{C}\right.$ 82.0), $C-9\left(\delta_{C} 35.6\right)$, and $C-10\left(\delta_{C} 60.7\right)$, and from H-6 $\left(\delta_{H} 5.78\right)$ to $\mathrm{C}-5\left(\delta_{C} 37.2\right), \mathrm{C}-7$, and $\mathrm{C}-11$ confirmed the presence of an $\alpha-$ methyl- $y$-butyrolactone moiety with a hydroxyl group at C-12. Thus, the double bond was located in the lactone ring instead of the exocyclic methylene group that is usually seen in germacranolides. HMBC correlations from $\mathrm{H}_{3}-14\left(\delta_{H} 1.43\right)$ to $\mathrm{C}-1, \mathrm{C}-9$, and C10 confirmed the attachment of the methyl at $\mathrm{C}-10$ next to an epoxy moiety. $\mathrm{HMBC}$ correlations from $\mathrm{H}-3\left(\delta_{H} 4.11\right)$ to $\mathrm{C}-1$ and C-4 $\left(\delta_{C} 37.1\right)$ corroborated the hydroxyl group at C-3 $\left(\delta_{C} 74.1\right)$. The HMBC correlations from $\mathrm{H}-1\left(\delta_{H} 3.48\right)$ to $\mathrm{C}-2\left(\delta_{C} 27.4\right)$ and $\mathrm{C}-$
$3\left(\delta_{C} 74.1\right)$ and from $\mathrm{H}_{3}-15\left(\delta_{H} 0.94\right)$ to $\mathrm{C}-4$ and $\mathrm{C}-3$ corroborated the planar structure of $\mathbf{1}(\triangleright$ Fig. 2 ).

Analysis of the NOESY spectrum established the relative configuration of 1 . Cross-peaks between $\mathrm{H}-6\left(\delta_{H} 5.78\right)$ and $\mathrm{H}-1\left(\delta_{H}\right.$ 3.48) and between $\mathrm{H}-1, \mathrm{H}_{3}-14$, and $\mathrm{H}_{\alpha}-2\left(\delta_{H} 2.29\right)$ indicated that they were all located on the same face of the molecule. The crosspeak between $\mathrm{H}_{\beta}-2\left(\delta_{H} 1.60\right)$ and $\mathrm{H}-3$ confirmed the $\alpha$ orientation of the hydroxyl group at $\mathrm{C}-3$, and the NOESY correlation between $\mathrm{H}_{\beta}-5\left(\delta_{H} 1.90\right)$ and $\mathrm{H}-4\left(\delta_{H} 2.37\right)$ confirmed the $\alpha$ orientation of the methyl group at $\mathrm{C}-4$. The configuration of stereogenic centers of 1 was established by ECD spectroscopy as $3 R, 4 S, 6 S$ given that the experimental ECD spectrum of 1 was in good agreement with the spectrum calculated for the 3R,4S,6S stereoisomer ( $\bullet$ Fig. 3 ).

Compound 2 had a molecular formula of $\mathrm{C}_{16} \mathrm{H}_{22} \mathrm{O}_{6}$, as deduced from the HRESIMS $\left(\mathrm{m} / \mathrm{z} 311.1490[\mathrm{M}+\mathrm{H}]^{+}\right.$; calcd. $311.1489)$, corresponding to 6 indices of hydrogen deficiency. The ${ }^{1} \mathrm{H}$ NMR data of 2 ( $\triangleright$ Table 2 ) were similar to those of 1 . The 

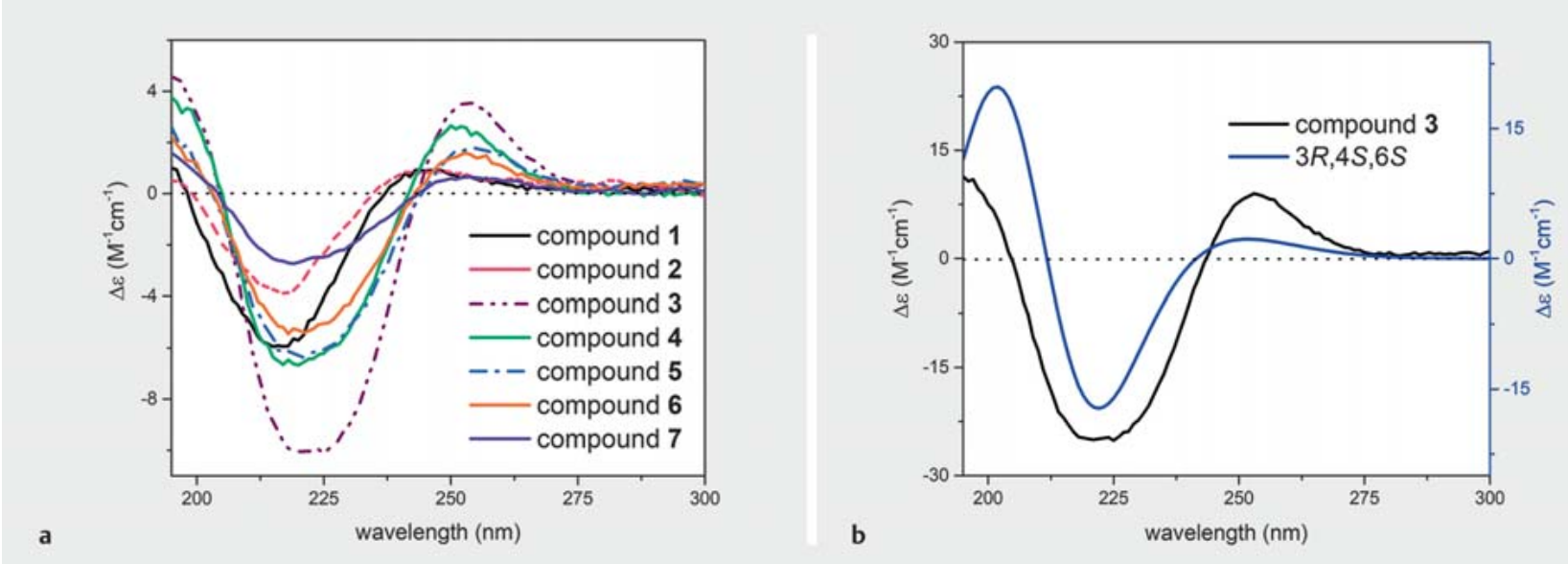

- Fig. 3 a Experimental ECD spectra of compounds 1-7 in MeOH. b Comparison of experimental and TDDFT calculated ECD spectra of compound 3.

major differences were in the presence of an additional aldehyde proton $\left(\delta_{H} 8.0\right)$ attached to the carbonyl carbon at $\delta_{C} 161.0$. Also, the carbinolic methine proton at $\mathrm{C}-3$ exhibited a paramagnetic shift from $4.11 \mathrm{ppm}$ in 1 to $5.06 \mathrm{ppm}$ in 2 and showed an HMBC correlation to the formyl group. Thus, compound 2 was the formyl ester of 1 . The experimental ECD spectrum of 2 was similar to that of 1 , and the configuration of stereogenic centers was thus established as $3 R, 4 S, 6 S$.

The HRESIMS spectrum of compound 3 showed a molecular ion at $\mathrm{m} / \mathrm{z} 267.1588[\mathrm{M}+\mathrm{H}]^{+}$(calcd. 267.1591), corresponding to a formula of $\mathrm{C}_{15} \mathrm{H}_{22} \mathrm{O}_{4}$. 1D and 2D NMR spectra suggested a germacranolide scaffold. Compared to 1 , the structural differences of 3 were in the presence of 2 additional olefinic carbons at $\delta_{C} 125.7$ and 134.3 instead of 2 oxygenated carbons in 1 . HMBC correlations from $\mathrm{H}_{3}-14\left(\delta_{H} 1.64\right)$ to $\mathrm{C}-9\left(\delta_{C} 36.5\right), \mathrm{C}-10\left(\delta_{C} 134.3\right)$ and $C-1\left(\delta_{C} 126.1\right)$ confirmed the location of this double bond between $\mathrm{C}-1$ and $\mathrm{C}-10$. The relative configuration of 3 was established by NOESY data. A cross-peak between $\mathrm{H}-3\left(\delta_{H} 3.77\right)$ and $\mathrm{H}-4\left(\delta_{H} 2.12\right)$ indicated that they were cofacial with syn orientation. The experimental ECD spectrum of 3 showed 2 positive cotton effects (CE) at 255 and $205 \mathrm{~nm}$ along with a negative CE at $225 \mathrm{~nm}$ which were due to $\pi-\pi^{*}$ transition of the lactone moiety. The ECD spectra for all possible stereoisomers of 3 were calculated, and the spectrum of the $3 R, 4 S, 6 S$ stereoisomer showed excellent match with the experimental spectrum ( $\vee$ Fig. 3). Thus, the absolute configuration of 3 was established as $3 R, 4 S, 6 S$.

Compound 4 had a molecular formula of $\mathrm{C}_{16} \mathrm{H}_{23} \mathrm{O}_{5}$ (HRESIMS $\mathrm{m} / \mathrm{z} 295.1542[\mathrm{M}+\mathrm{H}]^{+}$, calcd. 295.1540). The NMR data ( $\triangleright$ Tables 1 and 2 ) of 4 closely reassembled those of 3 except for the presence of a formyl residue $\left(\delta_{H} 8.03\right.$ and $\left.\delta_{C} 160.1\right)$ as in compound 2 . The HMBC correlation from the formyl hydrogen to $C-3\left(\delta_{C} 75.0\right)$ confirmed the attachment at $\mathrm{C}-3$. The relative configuration was established by an NOESY spectrum and corresponded with that of 3 . The ECD spectrum of 4 corresponded to that of 3 , and the absolute configuration of 4 was thus established as $3 R, 4 S, 6 S$.

HRESIMS data of compound $5\left(\mathrm{~m} / \mathrm{z} 309.1698[\mathrm{M}+\mathrm{H}]^{+}\right.$, calcd. 309.1697) indicated a molecular formula of $\mathrm{C}_{17} \mathrm{H}_{24} \mathrm{O}_{5}$. The NMR data ( $\triangleright$ Tables 1 and 2 ) closely reassembled to those of 3 . However, an extra methyl signal $\left(\delta_{H} 1.99\right.$ and $\left.\delta_{C} 20.8\right)$ and an extra carbonyl resonance $\left(\delta_{C} 169.7\right)$ were present in 5 . HMBC correlations from the additional methyl $\left(\delta_{H} 1.99\right)$ and from $\mathrm{H}_{2}-12\left(\delta_{H} 4.7\right)$ to the carbonyl group at $\delta_{C} 169.7$, together with the downfield shift of $\mathrm{H}_{2}-12\left(\delta_{H} 4.7\right.$ in 5 vs. 4.22 in 3), confirmed that 5 was an acetyl derivative of 5 . The NOESY and ECD spectra of 5 closely resembled those of 3 , and the absolute configuration was established as $3 R, 4 S, 65$.

A molecular formula of $\mathrm{C}_{15} \mathrm{H}_{20} \mathrm{O}_{5}$ (HRESIMS m/z 303.1205 $[\mathrm{M}+\mathrm{Na}]^{+}$, calcd. 303.1203) was assigned to compound 6 . The NMR data were reminiscent of a germacranolide skeleton bearing a double bond between C-1 and C-10. Compared to 3, diagnostic differences were in the presence of an additional carbonyl ( $\delta c$ 210.0) and in the absence of a methylene group. In the HMBC spectrum, a correlation of one of the diastereotopic methylene protons $\left(\delta_{H} 1.12\right)$ at $C-9$ to this carbonyl group observed. Hence, the carbonyl group was at $\mathrm{C}-8$. The relative configuration was established with the aid of the NOESY spectrum. The ECD spectrum ( $\vee$ Fig. 3 ) closely resembled that of 3 , and the absolute configuration of compound 6 was established as $3 R, 4 S, 6 S$.

Compound 7 had the same molecular formula as $3\left(\mathrm{C}_{15} \mathrm{H}_{22} \mathrm{O}_{4}\right.$; HRESIMS $m / z$ 267.1588 [M + H] $]^{+}$, calcd. 267.1591). The NMR data closely resembled those of 3 , In the COSY spectrum a correlation of $\mathrm{H}_{2}-8\left(\delta_{H} 2.40\right.$ and 2.92) to $\mathrm{H}-9\left(\delta_{H} 5.75\right)$ was observed, and in the HMBC spectrum these 2 diastereotopic protons correlated to 4 olefinic carbons $\left(\delta_{C} 125.7,126.3,134.3\right.$, and 166.9) ( $\bullet$ Fig. 2). Thus, the double bond was located between C-9 and C-10. The relative configuration of 7 was determined from NOESY correlations and was in accordance with that of 3 , and the ECD spectrum also matched with that of $\mathbf{3}(\boldsymbol{\vee}$ Fig. $\mathbf{3}$ ). Thus, the absolute configuration was established as $3 R, 4 S, 6 S$.

The in vitro antiprotozoal activity and cytotoxicity of compounds 1-7 was evaluated against Trypanosoma brucei rhodesiense and rat myoblast (L6) cells, respectively, and the selectivity indices (SI) for tested compounds were calculated ( $\triangleright$ Table 3 ). Compounds 4 and 5 showed the most potent inhibitory activity 
against T.b. rhodesiense with $\mathrm{IC}_{50}$ values $5.1 \mu \mathrm{M}$ (SI 3.9) and $10.2 \mu \mathrm{M}$ (SI 4.0), respectively. Epoxides 1 and 2 exhibited only marginal activity, while 3,6 , and 7 were inactive at the highest test concentration. From the limited number of compounds tested here, only preliminary observations on structural requirements for activity are possible. When comparing active compound 4 with marginally active epoxide 2 , it seems that the conformation of the 10-membered ring affects the degree of activity. A formyl or acetyl moiety as in $\mathbf{4}$ and $\mathbf{5}$ appears to enhance activity when compared to parent compound 3. Numerous sesquiterpene lactones with different scaffolds reportedly show in vitro activity against T.b. rhodesiense [18-21]. However, these compounds all bear an $\alpha, \beta$-unsaturated carbonyl group that may react with biological nucleophiles such as thiol groups of cysteine residues in proteins [18]. In contrast, the $\alpha, \beta$-unsaturated carbonyl group in active compounds 4 and $\mathbf{5}$ cannot act as a Michael acceptor. Additional, structurally related germacranolides need to be tested to unravel the features that are relevant for activity.

NMR spectra (1D and 2D) of compounds 1-7 as well as the dose-response curves leading to the $\mathrm{IC}_{50}$ determination of compounds 1, 2, 4, and 5 are available as Supporting Information.

\section{Materials and Methods}

\section{General experimental procedures}

The JASCO P-2000 digital polarimeter was used for measuring optical rotation. UV spectra were recorded using a Shimadzu UV2501PC spectrophotometer. ECD spectra were recorded in $\mathrm{MeOH}$ on a Chirascan (Applied Photophysics) spectrometer with 1-mm path precision cells (110 QS, Hellma Analytics), and data were analyzed with Pro-Data V2.4 software. NMR spectra were recorded at a target temperature of $18^{\circ} \mathrm{C}$ on a Bruker Avance III 500-MHz spectrometer operating at $500.13 \mathrm{MHz}$ for ${ }^{1} \mathrm{H}$ and $125.77 \mathrm{MHz}$ for ${ }^{13} \mathrm{C}$. A 1-mm TXI-microprobe with z-gradient was used for ${ }^{1} \mathrm{H}$ detected experiments. ${ }^{13} \mathrm{C}$ NMR spectra were recorded with a 5$\mathrm{mm}$ BBO probe head with z-gradient. Spectra were analyzed using Bruker TopSpin 3.5 software. Deuterated solvents for NMR (100\% D) were purchased from Armar Chemicals. HRESIMS data were recorded in positive ion mode on an Agilent 1290 Infinity system with an Agilent 6540 UHD Accurate-Mass Quadrupole Time-ofFlight detector (G6540A). HPLC separations were performed on a Knauer HPLC system consisting of a mixing pump with degasser module, photodiode array (PDA) detector, and an autosampler. Knauer Eurospher $\Pi 100-5$ RP C18 (5 $\mu \mathrm{m}, 4.6 \times 250$ mm i.d.) and SunFire Prep C18 ODB ( $5 \mu \mathrm{m}, 19 \times 50 \mathrm{~mm}$ i. d. $)$ columns were used for analytical and semipreparative separations, respectively. Solvents used for extraction and column chromatography were of technical grade and were distilled before use. HPLC-grade solvents (Merck) were used for HPLC. Silica gel (70-230 mesh) for column chromatography, precoated silica gel $F_{254}(20 \times 20 \mathrm{~cm})$ plates, anisaldehyde, glacial acetic acid, and sulfuric acid were all from (Merck).

\section{Plant material}

Aerial parts and flowers of $T$. sonbolii were collected from Takab, Baderloo village, West Azerbaijan Province, Iran, in June 2015 and
- Table 3 In vitro activity of compounds 1-7 against T.b. rhodesiense (STIB 900) and cytotoxicity in L6 cells.

\begin{tabular}{|c|c|c|}
\hline Compound & T. b. rhodesiense $\mathrm{IC}_{50}{ }^{\mathrm{a}}$ & L6 cells \\
\hline 1 & $50.3(44.1-56.2) ; 3.0^{b}$ & $150.9(170.6-194.1)$ \\
\hline 2 & $88.1(55.5-123.6) ; 3.3^{b}$ & $287.0(282.3-291.7)$ \\
\hline 3 & $>200$ & - \\
\hline 4 & $10.2(9.5-10.9) ; 4.0^{b}$ & $40.9(39.7-42.1)$ \\
\hline 5 & $5.1(1.7-8.5) ; 3.9^{b}$ & $19.9(17.9-21.9)$ \\
\hline 6 & $>200$ & - \\
\hline 7 & $>200$ & - \\
\hline Melarsoprol & 0.003 & \\
\hline Podophyllotoxin & & 0.005 \\
\hline \multicolumn{3}{|c|}{$\begin{array}{l}{ }^{a} \text { Values are expressed in } \mu \mathrm{M} \text {. Each value corresponds to the mean } \\
\left(\mathrm{Cl} 95 \% \text { ) from } 2 \text { independent assays. }{ }^{b} \mathrm{SI}: \mathrm{IC}_{50} \text { in } \mathrm{L} 6 \text { cells divided by } \mathrm{IC}_{50}\right. \\
\text { in the titled parasitic strain. }\end{array}$} \\
\hline
\end{tabular}

identified by Dr. Ali Sonboli. A voucher specimen (MPH-2556) has been deposited at the Herbarium of the Medicinal Plants and Drugs Research Institute of Shahid Beheshti University, Tehran, Iran.

\section{Extraction and preparative isolation}

Air-dried flowers of $T$. sonbolii (190 g) were powdered and macerated with acetone $(5 \times 2 \mathrm{~L})$. The combined extracts were concentrated to dryness, and the residue $(7 \mathrm{~g})$ was subjected to silica gel column chromatography (70-230 mesh, $45.0 \times 300 \mathrm{~mm}, 230 \mathrm{~g})$ using a step gradient of $n$-hexane-EtOAc (100:0 $\rightarrow 0: 100)$, followed by EtOAc/MeOH (100:0 $\rightarrow 50: 50)$. A total of 55 fractions of $250 \mathrm{~mL}$ each were collected and pooled after TLC analysis (detection at $254 \mathrm{~nm}$ and after spraying with anisaldehyde-sulfuric acid reagent) to 12 fractions. Fraction $8(110 \mathrm{mg}$; eluted with $n$ hexane-EtOAc [50:50]) was separated by preparative HPLC $\left(\mathrm{MeCN} / \mathrm{H}_{2} \mathrm{O}, 60: 40, \mathrm{v} / \mathrm{v}\right)$ to yield $5\left(5.6 \mathrm{mg}, t_{R} 10.3 \mathrm{~min}\right)$. Fraction 11 (200 mg; eluted with $n$-hexane-EtOAc [25:75]) was separated by preparative $\mathrm{HPLC}\left(\mathrm{MeCN} / \mathrm{H}_{2} \mathrm{O}, 40: 60, \mathrm{v} / \mathrm{v}\right)$ to yield compounds 1 ( $2 \mathrm{mg}, t_{R} 12.3 \mathrm{~min}$ ) and 3 (4 mg, $\left.t_{R} 16.7 \mathrm{~min}\right)$.

The air-dried aerial parts of $T$. sonbolii $(1.6 \mathrm{~kg})$ were milled and macerated with ethyl acetate $(5 \times 7 \mathrm{~L})$. The extract was concentrated in vacuo to afford $60 \mathrm{~g}$ of a dark gummy residue. The residue was separated on a silica gel column (70-230 mesh, $60.0 \times 1180 \mathrm{~mm}, 850 \mathrm{~g}$ ) with a step gradient of $n$-hexane-EtOAc $(100: 0 \rightarrow 0: 100)$ as eluent, followed by EtOAc containing increasing concentrations of $\mathrm{MeOH}$ (up to $100 \%$ ). A total of 21 fractions were collected on the basis of TLC analysis. Fraction $12(1.8 \mathrm{~g}$; eluted with $n$-hexane-EtOAc [30:70]) was separated on a silica gel column (70-230 mesh, $25 \times 450 \mathrm{~mm}, 150 \mathrm{~g})$ eluted with $\mathrm{CH}_{2} \mathrm{Cl}_{2} /\left(\mathrm{CH}_{3}\right)_{2} \mathrm{CO}(70: 30)$. Fractions were pooled on the basis of TLC patterns to give 5 subfractions $\left(\mathrm{F} 12_{1}-\mathrm{F} 12_{5}\right)$. Subfraction $\mathrm{F}_{12}(60 \mathrm{mg})$ was separated on a silica gel column (70-230 mesh, $20 \times 600 \mathrm{~mm}, 90 \mathrm{~g})$ using $\mathrm{CH}_{2} \mathrm{Cl}_{2} /\left(\mathrm{CH}_{3}\right)_{2} \mathrm{CO}(80: 20)$ as mobile phase, and 5 subfractions $\left(\mathrm{F} 12_{3.1}-\mathrm{F} 12_{3.5}\right)$ were obtained. The precipitate of subfraction $\mathrm{F}_{12} 2_{3.3}$ was recrystallized from $\left(\mathrm{CH}_{3}\right)_{2} \mathrm{CO}$ to afford compound $4(1.2 \mathrm{mg})$. F12 4 was separated by preparative 
HPLC (MeCN/H $\left.\mathrm{H}_{2} \mathrm{O}, 50: 50, \mathrm{v} / \mathrm{v}\right)$ to yield compounds 2 (1.5 mg, $t_{R}$ $13.1 \mathrm{~min})$ and $6\left(2.5 \mathrm{mg}, t_{R} 17.5 \mathrm{~min}\right)$. Fraction 14 (120 mg; eluted with $n$-hexane-EtOAc [45:55]) was separated by preparative $\mathrm{HPLC}\left(\mathrm{MeCN} / \mathrm{H}_{2} \mathrm{O}, 60: 40, \mathrm{v} / \mathrm{v}\right)$ to yield compounds 7 (2.5 mg, $\left.t_{R} 14.3 \mathrm{~min}\right)$. The purity of the isolated compounds was assessed by ${ }^{1} \mathrm{H}$ NMR and HPLC analyses and found to be $>95 \%$ for compounds $1-5$ and $>90 \%$ for $6-7$.

Compound 1: White powder; $[\alpha]_{\mathrm{D}}^{25}=+25.9$ (c 1.0, MeOH); UV $(\mathrm{MeOH}) \lambda_{\max }(\log \varepsilon) 218(4.03) \mathrm{nm} ; \mathrm{ECD}(\mathrm{MeOH}) 217 \mathrm{~nm}(\Delta \varepsilon$ - 13.89) and $247 \mathrm{~nm}(\Delta \varepsilon+2.08)$. For ${ }^{1} \mathrm{H}$ and ${ }^{13} \mathrm{C}$ NMR spectroscopic data, see - Tables 1 and 2; HRESITOFMS m/z 283.1543 $[\mathrm{M}+\mathrm{H}]^{+}$(calcd. for 283.1540).

Compound 2: White powder; $[\alpha]_{\mathrm{D}}^{25}=+3.3$ (c 1.0, MeOH); UV $(\mathrm{MeOH}) \lambda_{\max }(\log \varepsilon) 220$ (3.33) nm; ECD (MeOH) $217 \mathrm{~nm}(\Delta \varepsilon$ - 2.06) and $250 \mathrm{~nm}(\Delta \varepsilon+0.55)$. For ${ }^{1} \mathrm{H}$ and ${ }^{13} \mathrm{C}$ NMR spectroscopic data, see $>$ Tables 1 and 2; HRESITOFMS m/z $311.1490[\mathrm{M}+\mathrm{H}]^{+}$ (calcd. for 311.1489).

Compound 3: White powder; $[\alpha]_{\mathrm{D}}^{25}=+9.9$ (c 1.0, MeOH); UV $(\mathrm{MeOH}) \lambda_{\max }(\log \varepsilon) 211$ (4.04) nm; ECD (MeOH) $224 \mathrm{~nm}(\Delta \varepsilon$ - 24.71) and $254 \mathrm{~nm}(\Delta \varepsilon+8.81)$. For ${ }^{1} \mathrm{H}$ and ${ }^{13} \mathrm{C}$ NMR spectroscopic data, see - Tables 1 and 2; HRESITOFMS m/z 267.1588 $[\mathrm{M}+\mathrm{H}]^{+}$(calcd. for 267.1591).

Compound 4: White powder; $[\alpha]_{\mathrm{D}}^{25}=+13.7$ (c 1.0, MeOH); UV $(\mathrm{MeOH}) \lambda_{\max }(\log \varepsilon) 267$ (5.13) nm; ECD (MeOH) $220 \mathrm{~nm}(\Delta \varepsilon$ - 14.95) and $252 \mathrm{~nm}(\Delta \varepsilon+5.88)$. For ${ }^{1} \mathrm{H}$ and ${ }^{13} \mathrm{C}$ NMR spectroscopic data, see - Tables 1 and 2; HRESITOFMS m/z 295.1542 $[\mathrm{M}+\mathrm{H}]^{+}$(calcd. for 295.1540).

Compound 5: White powder; $[\alpha]_{\mathrm{D}}^{25}=+13.2$ (c 1.0, MeOH); UV $(\mathrm{MeOH}) \lambda_{\max }(\log \varepsilon) 265$ (5.13) nm; ECD (MeOH) $221 \mathrm{~nm}(\Delta \varepsilon$ - 13.64) and $255 \mathrm{~nm}(\Delta \varepsilon+3.78)$. For ${ }^{1} \mathrm{H}$ and ${ }^{13} \mathrm{C}$ NMR spectroscopic data, see $>$ Tables 1 and 2; HRESITOFMS m/z 309.1698 $[\mathrm{M}+\mathrm{H}]^{+}$(calcd. for 309.1697).

Compound 6: White powder; $[\alpha]_{\mathrm{D}}^{25}=+16.2$ (c 1.0, MeOH); UV $(\mathrm{MeOH}) \lambda_{\max }(\log \varepsilon) 217$ (3.87) nm; ECD (MeOH) $218 \mathrm{~nm}(\Delta \varepsilon$ - 12.82) and $253 \mathrm{~nm}(\Delta \varepsilon+3.73)$. For ${ }^{1} \mathrm{H}$ and ${ }^{13} \mathrm{C}$ NMR spectroscopic data, see - Tables 1 and 2; HRESITOFMS m/z 303.1205 $[\mathrm{M}+\mathrm{Na}]^{+}$(calcd. for 303.1203).

Compound 7: White powder; $[\alpha]_{D}^{25}=+14.929$ (c 1.0, MeOH); UV (MeOH) $\lambda_{\max }(\log \varepsilon) 214$ (3.19) nm; ECD (MeOH) $218 \mathrm{~nm}(\Delta \varepsilon$ - 12.82) and $253 \mathrm{~nm}(\Delta \varepsilon+3.73)$. For ${ }^{1} \mathrm{H}$ and ${ }^{13} \mathrm{C}$ NMR spectroscopic data, see $>$ Tables 1 and 2; HRESITOFMS m/z 267.1588 $[\mathrm{M}+\mathrm{H}]^{+}$(calcd. for 267.1591).

\section{ECD computational details}

Conformational analysis of 3 was performed with MacroModel 9.8 software (Schrödinger LLC) employing the OPLS 2005 (Optimized Potential for Liquid Simulations) force field in $\mathrm{H}_{2} \mathrm{O}$. Conformers occurring within a $2 \mathrm{kcal} / \mathrm{mol}$ energy window from the global minimum were selected for geometrical optimization and energy calculation using DFT-B3LYP/6-31G** in $\mathrm{MeOH}$ with the Gaussian 09 program package [22]. The vibrational evaluation was done at the same level to confirm minima. Excitation energy (denoted by wavelength in $\mathrm{nm})$, rotatory strengths dipole velocity $\left(R_{\text {vel }}\right)$, and dipole length $\left(R_{\text {len }}\right)$ were calculated in MeOH by TD-DFT/B3LYP/6$31 \mathrm{G}^{* *}$ using the selfconsistent reaction field (SCRF) method with the conductor-like polarizable continuum model (CPCM). ECD curves were obtained by rotatory strengths with a half-band of
$0.25 \mathrm{eV}$ and UV shift using SpecDis v1.64 [23]. ECD spectra were calculated from the spectra of individual conformers according to their contribution calculated by Boltzmann weighting.

\section{In vitro biological testing}

The in vitro activities against the protozoan parasites T.b. rhodesiense (STIB900) bloodstream forms and cytotoxicity in L6 cells (rat skeletal myoblasts) were determined at the Swiss Tropical and Public Health Institute as reported previously [24, 25]. Assays were run in singleton and repeated at least 2 times. The positive control podophyllotoxin was purchased from Sigma, and Melarsoprol was received from the World Health Organization. Their purity was $>95 \%$ according to the suppliers.

\section{Activity against T. b. rhodesiense STIB900}

The stock was isolated in 1982 from a human patient in Tanzania and after several mouse passages cloned and adapted to axenic culture conditions [26]. Minimum essential medium (MEM) $(50 \mu \mathrm{L})$ supplemented with $25 \mathrm{mM}$ HEPES, $1 \mathrm{~g} / \mathrm{L}$ additional glucose, $1 \%$ MEM nonessential amino acids (100×), $0.2 \mathrm{mM} 2$-mercaptoethanol, $1 \mathrm{mM} \mathrm{Na}$-pyruvate, and 15\% heat inactivated horse serum was added to each well of a 96-well microtiter plate. Compounds were dissolved in DMSO $(10 \mathrm{mg} / \mathrm{mL})$ and stored at $-20^{\circ} \mathrm{C}$ until testing. Final test concentrations did not exceed a $1 \%$. DMSO and assays were done at least 3 times independently. Serial dilutions of compounds prepared to cover in a range from 100 to $0.001 \mu \mathrm{g} / \mathrm{mL}$ were prepared. Then 104 bloodstream forms of $T$. $b$. rhodesiense STIB 900 in $50 \mu \mathrm{L}$ of medium were added to each well and the plate incubated at $37^{\circ} \mathrm{C}$ under a $5 \% \mathrm{CO}_{2}$ atmosphere for $72 \mathrm{~h}$. Alamar blue solution $(10 \mu \mathrm{L}, 12.5 \mathrm{mg}$ resazurin dissolved in $100 \mathrm{~mL}$ distilled water) were then added to each well and incubation continued for a further 2-4 h [27]. After that he plate was read in a Spectramax Gemini XS microplate fluorometer (Molecular Devices Corporation) using an excitation wavelength of $536 \mathrm{~nm}$ and emission wavelength of $588 \mathrm{~nm}$. The IC 50 values were calculated by linear regression [28] from the sigmoidal dose inhibition curves using SoftmaxPro software (Molecular Devices Cooperation). Melarsoprol (received from WHO) is used as control.

\section{In vitro cytotoxicity with L-6 cells}

Assays were performed in 96-well microtiter plates, each well containing $100 \mu \mathrm{L}$ of RPMI 1640 medium supplemented with $1 \% \mathrm{~L}$ glutamine $(200 \mathrm{mM})$ and $10 \%$ FBS and $4000 \mathrm{~L}-6$ cells (a primary cell line derived from rat skeletal myoblasts) $[29,30]$. Serial drug dilutions of eleven 3-fold dilution steps covering a range from 100 to $0.002 \mu \mathrm{g} / \mathrm{mL}$ were prepared. After $70 \mathrm{~h}$ of incubation, the plates were inspected under an inverted microscope to assure growth of the controls and sterile conditions. Ten microliters of alamarBlue was then added to each well and the plates incubated for another $2 \mathrm{~h}$. Then the plates were read with a Spectramax Gemini XS microplate fluorometer (Molecular Devices Cooperation) using an excitation wave length of $536 \mathrm{~nm}$ and an emission wave length of $588 \mathrm{~nm}$. The $\mathrm{IC}_{50}$ values were calculated by linear regression [28] from the sigmoidal dose inhibition curves using SoftmaxPro software (Molecular Devices Cooperation). 


\section{Supporting information}

NMR spectra (1D and 2D) of compounds 1-7 as well as the doseresponse curves leading to the $\mathrm{IC}_{50}$ determination of compounds $1,2,4$, and 5 are available as Supporting Information.

\section{Acknowledgements}

We are grateful to Shahid Beheshti University Research Council for financial support of this work. ECD spectra were measured at the Biophysics Facility, Biozentrum, University of Basel. Thanks are due to Monica Cal (Swiss Tropical and Public Health Institute) and T. Hettich (Institute for Chemistry and Bioanalytics, University of Applied Sciences, Muttenz) for the in vitro assays and the HRESIMS data, respectively. Ombeline Danton (University of Basel) is gratefully acknowledged for measuring the NMR spectra.

\section{Conflict of Interest}

The authors declare no conflict of interest.

\section{References}

[1] Stuart K, Brun R, Croft S, Fairlamb A, Gürtler RE, McKerrow J, Reed S, Tarleton R. Kinetoplastids: related protozoan pathogens, different diseases. J Clin Invest 2008; 118: 1301-1310

[2] WHO website. Malaria. Available at http://www.who.int/en/news-room/ fact-sheets/detail/malaria. Accessed June 11, 2018

[3] Soeiro MN, De Souza EM, Stephens CE, Boykin DW. Aromatic diamidines as antiparasitic agents. Expert Opin Investig Drugs 2005; 14: 957-972

[4] Mishina YV, Krishna S, Haynes RK, Meade JC. Artemisinins inhibit Trypanosoma cruzi and Trypanosoma brucei rhodesiense in vitro growth. Antimicrob Agents Chemother 2007; 51: 1852-1854

[5] Oberprieler C, Himmelreich S, Vogt R. A new subtribal classification of the tribe Anthemideae (Compositae). Willdenowia 2007; 37: 89-114

[6] Kazemi M, Sonboli A, Zare Maivan H, Kazempour Osaloo S. A taxonomic reassessment of the Tanacetum aureum (Asteraceae, Anthemideae) species group: insights from morphological and molecular data. Turk J Botany 2014; 38: 1259-1273

[7] The International Plant Names Index (IPNI). Available at http://www.ipni. org. Accessed June 22, 2018

[8] Sonboli A, Stroka K, Kazempour SO, Oberpriele C. Molecular phylogeny and taxonomy of Tanacetum L. (Compositae, Anthemideae) inferred from nrDNA ITS and cpDNA trnH-psbA sequence variation. Plant Syst Evol 2012; 298: 431-444

[9] Mozzafarian V. Notes on the tribe Anthemideae (Compositae), new species, new records and new combinations for Iran. Iran J Bot 2005; 11 : $115-127$

[10] Firozy M, Talebpour Z, Sonboli A. Essential oil composition and antioxidant activities of the various extracts of Tanacetum sonbolii Mozaff. (Asteraceae) from Iran. Nat Prod Res 2012; 26: 2204-2207

[11] Esmaeili MA, Sonboli A, Ayyari Noushabadi M. Antioxidant and protective properties of six Tanacetum species against hydrogen peroxide-induced oxidative stress in K562 cell line: a comparative study. Food Chem 2010; 121: 148-155

[12] Naderi F, Azhdari-Zarmehri H, Erami E, Sonboli A, Sofiabadi M, Mohammad-Zadeh $\mathrm{M}$. The effect of Tanacetum sonbolii hydroalcholic extract on PTZ-induced seizures in male mice. J Med Plants 2012; 4: 193-201

[13] Sofiabadi M, Azhdari-Zarmehri H, Naderi F, Ghalandari-Shamami M, Sonboli A, Haghparast A. Effects of hydroalcoholic extract of Tanacetum sonbolii (Asteraceae) on pain-related behaviors during formalin test in mice. Basic Clin Neurosci 2014; 5: 162-168
[14] Mofidi Tabatabaei S, Salehi P, Moridi Farimani M, Neuburger M, De Mieri M, Hamburger M, Nejad-Ebrahimi S. A nor-diterpene from Salvia sahendica leaves. Nat Prod Res 2017; 31: 1758-1765

[15] Tabefam M, Farimani MM, Danton O, Ramseyer J, Kaiser M, Ebrahimi SN, Salehi P, Batooli H, Potterat O, Hamburger M. Antiprotozoal diterpenes from Perovskia abrotanoides. Planta Med 2018; 84: 913-919

[16] Farimani MM, Taleghani A, Aliabadi A, Aliahmadi A, Esmaeili MA, Sarvestani NN, Khavasi HR, Smieško M, Hamburger M, Ebrahimi SN. Labdane diterpenoids from Salvia leriifolia: absolute configuration, antimicrobial and cytotoxic activities. Planta Med 2016; 82: 1279-1285

[17] Goren N, Tahtasakal E. Sesquiterpenoids from Tanacetum argenteum subsp. canum var. canum. Phytochemistry 1997; 45: 107-109

[18] Schmidt T, Nour A, Khalid S, Kaiser M, Brun R. Quantitative structure antiprotozoal activity relationships of sesquiterpene lactones. Molecules 2009; 14: 2062-2076

[19] Kimani NM, Matasyoh JC, Kaiser M, Brun R, Schmidt T]. Anti-trypanosomatid elemanolide sesquiterpene lactones from Vernonia lasiopus $\mathrm{O}$. Hoffm. Molecules 2017; 22: 3-11

[20] Kimani NM, Matasyoh JC, Kaiser M, Brun R, Schmidt TJ. Antiprotozoal Sesquiterpene Lactones and Other Constituents from Tarchonanthus camphoratus and Schkuhria pinnata. J Nat Prod 2018; 81: 124-130

[21] Otoguro K, Iwatsuki M, Ishiyama A, Namatame M, Nishihara-Tukashima A, Kiyohara H, Hashimoto T, Asakawa Y, Mura S, Yamada H. In vitro antitrypanosomal activity of plant terpenes against Trypanosoma brucei. Phytochemistry 2011; 72: 2024-2030

[22] Frisch M, Trucks G, Schlegel H, Scuseria G, Robb M, Cheeseman J, Scalmani G, Barone V, Mennucci B, Petersson GA, Nakatsuji H, Caricato M, Li X, Hratchian HP, Izmaylov AF, Bloino J, Zheng G, Sonnenberg JL, Hada M, Ehara M, Toyota K, Fukuda R, Hasegawa J, Ishida M, Nakajima T, Honda Y, Kitao O, Nakai H, Vreven T, Montgomery JA, Peralta JE, Ogliaro F, Bearpark M, Heyd JJ, Brothers E, Kudin KN, Staroverov VN, Kobayashi R, Normand J, Raghavachari K, Rendell A, Burant JC, lyengar SS, Tomasi J, Cossi M, Rega N, Millam JM, Klene M, Knox JE, Cross JB, Bakken V, Adamo C, Jaramillo J, Gomperts R, Stratmann RE, Yazyev O, Austin AJ, Cammi R, Pomelli C, Ochterski JW, Martin RL, Morokuma K, Zakrzewski VG, Voth GA, Salvador P, Dannenberg J], Dapprich S, Daniels AD, Farkas O, Foresman JB, Ortiz JV, Cioslowski J, Fox DJ. Gaussian 09, Revision A02. Wallingford: Gaussian; 2009

[23] Bruhn T, Schaumloffel A, Hemberger Y, Bringmann G. SpecDis: quantifying the comparison of calculated and experimental electronic circular dichroism spectra. Chirality 2013; 25: 243-249

[24] Orhan I, Sener B, Kaiser M, Brun R, Tasdemir D. Inhibitory activity of marine sponge-derived natural products against parasitic protozoa. Mar Drugs 2010; 8: 47-58

[25] Zimmermann S, Kaiser M, Brun R, Hamburger M, Adams M. Cynaropicrin: the first plant natural product with in vivo activity against Trypanosoma brucei. Planta Med 2012; 78: 553-556

[26] Baltz T, Baltz D, Giroud C, Crockett ]. Cultivation in a semi-defined medium of animal infective forms of Trypanosoma brucei, T. equiperdum, T. evansi, T. rhodesiense and T. gambiense. EMBO J 1985; 4: 1273-1277

[27] Räz B, Iten M, Grether-Bühler Y, Kaminsky R, Brun R. The Alamar Blue ${ }^{\circledR}$ assay to determine drug sensitivity of African trypanosomes (T.b. rhodesiense and T.b. gambiense) in vitro. Acta Trop 1997; 68: 139-147

[28] Huber W, Koella JC. A comparison of three methods of estimating $\mathrm{EC}_{50}$ in studies of drug resistance of malaria parasites. Acta Trop 1993; 55: $257-$ 261

[29] Pagé B, Pagé M, Noel C. A new fluorometric assay for cytotoxic measurements in vitro. Int J Oncol 1993; 3: 473-476

[30] Ansar Ahmed S, Gogal RM, Walsh JE. A new rapid and simple non-radioactive assay to monitor and determine the proliferation of lymphocytes: an alternative to $[3 \mathrm{H}]$ thymidine incorporation assay. J Immunol Methods 1994; 170: 211-224 